\title{
Factors Hold Key to Job Satisfaction of the Human Resources: A Study on Titas Gas Transmission \& Distribution Company Limited
}

\author{
Md Nazmul Huda*, Md Abdus Sabur, Md Abu Sina, Md Mizanoor Rahman \\ Department of Accounting \& Information Systems, Islamic University, Kushtia, Bangladesh \\ Email address: \\ nazmuliu07@gmail.com (Md N. Huda),md.abdussubur@gmail.com (Md A. Sabur), drabusina1970@gmail.com (Md A. Sina), \\ pdmizanur@yahoo.com (Md M. Rahman) \\ ${ }^{*}$ Corresponding author
}

\section{To cite this article:}

Md Nazmul Huda, Md Abdus Sabur, Md Abu Sina, Md Mizanoor Rahman. Factors Hold Key to Job Satisfaction of the Human Resources: A Study on Titas Gas Transmission \& Distribution Company Limited. American Journal of Operations Management and Information Systems. Vol. 6, No. 2, 2021, pp. 21-28. doi: 10.11648/j.ajomis.20210602.12

Received: July 5, 2021; Accepted: July 14, 2021; Published: July 22, 2021

\begin{abstract}
Titas Gas Transmission and Distribution Company Limited is the largest gas distribution company in Bangladesh. A total numbers of employees 2100 have been working in this sector. To measure factors hold key to job satisfaction of the human resources of the company, a sample of 115 employees were selected from head office, Dhaka, Gazipur, Mymensingh, Narayanganj offices on a random purposive sampling basis and data were collected through closed end questionnaire from field study on offices. To ascertain job satisfaction, 13 factors like job security, salary, promotion, job status, working condition, supervision, award, relation, communication, duration, participation and training were chosen. Different types of statistical tools like descriptive statistics, regression analysis, factor analysis, Mann-Whitney U- Test and Kruskal Wallis Test were used for analyzing and interpreting data. The study revealed that low level salary holders were more dissatisfied. It is shown that higher level of pay holders was highly satisfied on autonomy, participation, location, training etc. The study further indicated that the employees of Dhaka and Narayanganj revealed in foremost facilities than that of other located areas. The study also identified three factors are Factor-1: Developed monetary based human resources facilities; Factor-2: Technologically advanced facilities based on working conditions; Factor-3: Satisfactory level of practicing autonomy to be the most influential that in fact reflect as key factors of job satisfaction of human resources of TGTDCL in Bangladesh. Management of the company should provide adequate facilities and allocated to the employees maintaining equity to ensure legal rights disregarding manipulations of outwards intervention that damages the congenial environment of the organizational environments and lead to dissatisfactions of the human resources.
\end{abstract}

Keywords: Job Satisfaction, Factors of Job Satisfaction, Job Status, Job Security, Participation

\section{Introduction}

In Bangladesh, Titas Gas Transmission and Distribution Company Limited (TGTDCL) is the largest gas distribution company which shared $58 \%$ of market in the natural gas distribution to its customers in the year of 2019 [15]. The company was established in 1964 by the government of Pakistan jointly with Shell Oil Company and started its commercial journey from April 28, 1968. After the independence of Bangladesh, on the basis of the agreement between Shell Oil Company and GOB in 1975 the possession was transferred to Petrobangla. It was also mentionable that TGTDCL was the highest tax payer in the energy sectors and receiving awarded from NBR (National Board of Revenue) in every year and huge amount was paid to national exchequer in the form of dividend, corporate tax, DSL (Debt Services Liabilities), CD, VAT etc. Based on the approved organogram-2006 (subsequently changes), the total numbers of employees are 3736 including 1243 no. of officers (Grade $10 \&$ Above as per pay scale) and 2493 staffs (below grade 
10) but currently working number of officers are 897 and staff only 1203 which indicates shortage of manpower of 1636 employees [13]. Officers as well as staffs (engineer, admin and accounts) are directly recruited from the open market through job vacancy advertisement in the daily newspapers and follow competitive written exam, viva voice and their salary is paid under the financial benefits recommended in the government pay scale of "Public Bodies and Autonomous" and promotion is made based on the seniority after collecting no objection certificate from the ACC (Anti-Corruption Commission) on the vacancy basis [16]. Officers are selected for both local and foreign training but staffs are engaged only local training.

Job satisfaction is psychological positions of an employee which are affected by multivariable factors regarding a set of facilities provided by the organization. The level of satisfaction varies in each of the individual on different facilities provided by the organization reflecting on productivity and profitability. The factors related to higher level of satisfaction of the human resources have the better impact on productivity and profitability which ensure the organization to touch the desired goal and to accomplish the sustainable development. TGTDCL has been suffering from dissatisfactory level of operating profits for long periods due to factors hold key to job satisfaction of human resources results negative impacts on productivity and profitability. The study will provide to identify the affecting factors of job satisfaction of the human resources which will helpful for the management to enhance productivity and profitability to have a better performance of the company.

The main objective of the study is to emphasize the touching factors that hold key to job satisfactions of the human resources in Titas Gas Transmission and Distribution Company Limited. On the other hand, to clarify the main objective the specific objectives are as follows:

a) To ascertain factors hold key to job satisfactions of the human resources of Titas Gas Transmission \& Distribution Company Limited;

b) To identify the problems hold back the job satisfactions of the human resources of Titas Gas Transmission \& Distribution Company Limited;

c) To provide some suggestions and recommendations to enhance the job satisfactions of the human resources of Titas Gas Transmission \& Distribution Company Limited.

\section{Review of Related Literatures}

A study conducted on the employees of Automobile industry, Punjab finds out the dimensions of job satisfactions and performance of the organization is positively correlated [12]. The researchers of this study demonstrated that the Jordanian industrial sector capable to minimize the amount of time and money currently spent on recruiting and training new employees due to the rapid employee turnover rate affected by the factors wages, organizational culture, benefits, job satisfaction, stress, training and development, promotion prospects, and job security [1]. The researchers stated that many factors affects job satisfaction like emotional intelligence, work method, job rotation, type of leadership, benefits, supervision, promotion, salary, and culture [6].

In another research work, it is stated that turnover and low productivity badly effect on the job satisfaction of an organization. The factors of job satisfaction must be considered and also concluded that long term job satisfaction is the solution for talent to stay in that organization which leaded performance as well as productivity [5]. The output of this study addresses job satisfaction is crucial but controversial issues in industrial psychology and behavioral management in organization. The study conducted on pharmaceutical company in Sikkim in India and highlights different factors affecting job satisfaction are employees motivation (organizational climate/environment), specific factors (wages, supervision, security, steadiness of employment, conditions of work, social relation of the job, prompt settlement of grievances, fair treatment of employer and other similar items), Socio-economic and personal factors ( age, sex, education, time of job incentives, working environment, education, duration of work etc.) [9]. The study attempts to investigate the factors affecting job satisfaction of bank employees were not satisfied in salary, incentives, relation with coworkers, working environment, working hours, transfer policy, performance appraisal system, training $\&$ development facilities and grievance handling \& safety measures [11].

The above mention literature reviews clearly identify the important factors for the under taken study that is not yet been done under the selected topic entitled "Factors Hold Key to Job Satisfaction of the Human Resources: A Study on Titus Gas Transmission \& Distribution Company Limited" for the energy sectors of the government in Bangladesh. This study will fulfill the research gap of the existing research works as well as broaden the experiences of the research area.

\section{Methodology of the Study}

Primary data has been used with a view to achieving the mentioned objectives in the study. Total number of permanent employees including general cadre, accounts cadre and technical cadre of Titas Gas Company Limited is approximately 2100 of which about 5 percent 115 persons have been selected purposively for the better convenient and availability to make maximum involvement from different groups and areas. The selection of 115 respondents has been taken from Head Office, Dhaka, Gazipur, Mymensingh and Narayanganj by the numbers of 47, 28, 20, 10 and 10 respectively. The data collection period of the study covers june-july 2020 by the questionnaire based on Likert scale. The collected data have processed, tested reliability and validity of data (Cronbach's Alpha $=0.856$ ) and applying the tools and techniques of descriptive statistics, regression analysis, factor analysis, Mann-Whitney U- Test and Kruskal Wallis Test with the help of SPSS Version-22. 


\section{Limitations}

The research has been conducted by collecting perceived satisfactions oriented primary information from limited number of respondents due to some unavoidable constraints. The study is confined to analysis and interpretations within primary data without making relationships with secondary information. Some limitations are:

1) Only 115 respondents have been selected out of 2100 employees due to time, cost and willingness of the respondents.

2) Other variables except mentioned 13 variables may affect the satisfaction level of employees which are not considered in the study.

3) All the departments and sections of the company are not selected for using sampling techniques.

As the test results of the reliability and validity to confirm the best fit of the data, the outcomes of the study hope to be reflected the objectives faultlessly.

\section{Term and Concepts}

For the understanding of the study a brief feature of some important terms have been furnished as below:

Job Security: Job security is an employee's perception that their job or future job is secure which depends upon redundancy rates, industry constraints rates, downsizing, recession and introduce new technology [3].

Pay (Salary): In Herzberg's theory (1959) pay or salary is treated as hygienic factors and indicate that the pay or salary structure should be appropriate and reasonable. It must be equal and competitive to those in the same industry in the same domain [14].

Promotion: Promotion means an improvement in pay, prestige, position and responsibilities of an employee within the organization. The new job is a promotion for the employee only when it carries increased responsibilities and enhanced pay. Promotion stimulates employees to higher productivity [2].

Working Condition: Comfortable working conditions are ranked an important factor also which indicates the condition of work should be safe, clean and healthy. Better the working condition less will be fatigue and more will be job satisfaction. Isolation is dissatisfactory to the workers [4].

Job Status: The status of the employees within the organization must be familiar and retained. Job status shows a very high correlation with intelligence, income and year of education. It has been found that employees are more dissatisfied in the jobs which have less social status and prestige [14].

Work Environment: Job satisfaction is associated with immediate work environment. Work environment plays a vital role since it influences job satisfaction, as employees are concerned with a comfortable physical work environment that will ultimately renders more positive level of job satisfaction [10].

Participation in Management: Participative management is a motivational tools used by the managers to motivate employees. Participation in management refers to the association of workers and their representatives with the decision making process. It is ensured when subordinates are involved in decision making at all levels like social, personnel and economic decision [2].

Training: Training involves an organized attempt to find out training needs of the individuals to meet the knowledge and skill which is needed not only perform current job but also the future needs and assuring the employees are capable of performing their jobs at acceptable level or more. It enriches and experiences of the managerial personnel to get maximum productivity in an organization [7].

Factor Analysis Related Concepts: Barleu's test of sphericity: Barleu's test of sphericity is a test statistic used to examine the hypothesis that the variables are uncorrelated in the population. In other words, the population correlation matrix is an identity matrix; each variable correlates perfectly with itself $(r=1)$ but has no correlation with the other variables $(\mathrm{r}=0)$. Eigenvalue: The eigenvalue represents the total variance explained by each factor. Factor loadings: Factor loadings are simple correlations between the variables and factors. Kaiser-Meyer-Olkin (KMO) measure of sample adequacy: The Kaiser-Meyer-Olkin (KMO) measure of sampling adequacy is an index used to examine the appropriateness of factor analysis. High values (between 0.5 and 1.0) indicate factor analysis is appropriate values below 0.5 imply that factor analysis may not be appropriate. Percentage of variance: This is the percentage of the total variance attributed to each factor [8].

\section{Analysis and Interpretations}

To reflect the outcomes of the study the following analysis and interpretations have been done:

Table 1. Descriptive statistics and Reliability statistics of selected items.

\begin{tabular}{|c|c|c|c|c|c|c|c|c|}
\hline \multirow{2}{*}{ Variables/Items } & \multirow{2}{*}{ Mean } & \multirow{2}{*}{ Mode } & \multirow{2}{*}{ C. V $(\%)$} & \multicolumn{5}{|c|}{ Respondents No. on Satisfactions Level } \\
\hline & & & & 1 & 2 & 3 & 4 & 5 \\
\hline Job Security $=(X 1)$ & 4.05 & 4.00 & 21.14 & 1 & 6 & 15 & 57 & 36 \\
\hline Salary=(X2) & 3.92 & 4.00 & 16.60 & 0 & 4 & 17 & 78 & 16 \\
\hline Promotion $=(\mathrm{X} 3)$ & 2.89 & 2.00 & 40.72 & 15 & 32 & 28 & 31 & 9 \\
\hline Job Status $=(X 4)$ & 3.38 & 4.00 & 25.25 & 2 & 16 & 39 & 52 & 6 \\
\hline Working Conditions $=(X 5)$ & 3.35 & 4.00 & 27.71 & 1 & 22 & 39 & 42 & 11 \\
\hline Award $=(X 7)$ & 3.01 & 4.00 & 39.25 & 12 & 34 & 19 & 41 & 9 \\
\hline
\end{tabular}




\begin{tabular}{|c|c|c|c|c|c|c|c|c|}
\hline \multirow{2}{*}{ Variables/Items } & \multirow{2}{*}{ Mean } & \multirow{2}{*}{ Mode } & \multirow{2}{*}{ C. V (\%) } & \multicolumn{5}{|c|}{ Respondents No. on Satisfactions Level } \\
\hline & & & & 1 & 2 & 3 & 4 & 5 \\
\hline Relation $=(\mathrm{X} 8)$ & 3.96 & 4.00 & 21.01 & 2 & 2 & 24 & 58 & 29 \\
\hline Autonomy $=(X 9)$ & 3.10 & 3.00 & 33.95 & 7 & 28 & 36 & 35 & 9 \\
\hline Communication $=(\mathrm{X} 10)$ & 3.17 & 4.00 & 34.99 & 6 & 32 & 26 & 39 & 12 \\
\hline Duration $=(X 11)$ & 4.06 & 4.00 & 18.82 & 2 & 3 & 9 & 73 & 28 \\
\hline Participation $=(\mathrm{X} 12)$ & 2.99 & 4.00 & 39.73 & 13 & 32 & 23 & 37 & 10 \\
\hline Training $=(\mathrm{X} 13)$ & 3.51 & 4.00 & 20.78 & 2 & 6 & 42 & 61 & 4 \\
\hline Overall mean & 3.46 & 4.00 & 28.13 & 5 & 18 & 26 & 51 & 15 \\
\hline \multicolumn{4}{|c|}{ Cronbach's Alpha of Reliability statistics for selected items } & & & & 0.8 & \\
\hline
\end{tabular}

Source: Compiled from primary data by SPSS version: $22, \mathrm{~N}=115$; highly Dissatisfied $=1$, Dissatisfied $=2$, No Comment $=3$, Satisfies $=4$ and highly Satisfied $=5$; if Cronbach's Alpha $>0.9$ Excellent, $>0.8$ Good, $>0.7$ Acceptable, $>0.6$ Questionable, $>0.5$ Poor, and $<0.5$ Unacceptable.

The Table 1 depicts the descriptive and reliability statistics of selected items for the study under the review periods. The lowest values of satisfaction level for each of the variables except salary found to be 1 indicating highly dissatisfied; only the variable salary in this regard shows value 2.00 means dissatisfied according to the opinions of the respondents. The highest value for each of the variables is 5.00 representing highly satisfied of some of the human resources. The mean values of the included variables found to be lower 2.89 to higher 4.05 . The modes of the maximum variables are 4.00; only the variable Promotion and
Autonomy shows this value 2 and 3 respectively. On the basis of an average (Overall mean) 5, 18, 26, 51 and 15 respondents out of 115 opined their satisfaction levels highly dissatisfied, dissatisfied, no comment, satisfied and highly satisfied respectively. Lower value of coefficient of variation C. V (\%) indicating better consistency whereas higher value of the same indicating less uniformity of the opinion of the respondents estimated in this regard. It is also found for the undertaken constructs the value of Cronbach's Alpha is 0.856 indicating good in measurement of the degree of internal consistency within a particular case.

Table 2. Rotated Component Matrix and its related measures of factors hold key to job satisfaction of the human resources.

\begin{tabular}{|c|c|c|c|}
\hline \multirow{2}{*}{ Items } & \multicolumn{3}{|l|}{ Factors } \\
\hline & Factor-1 & Factor-2 & Factor-3 \\
\hline Participation & 0.829 & & \\
\hline Communication & 0.739 & & \\
\hline Promotion & 0.737 & & \\
\hline Award & 0.697 & & \\
\hline Training & 0.691 & & \\
\hline Working conditions & & 0.779 & \\
\hline Job security & & 0.649 & \\
\hline Job status & & 0.501 & \\
\hline Autonomy & & & 0.718 \\
\hline Supervision & & & 0.698 \\
\hline Duration & & & 0.524 \\
\hline KMO and Bartlett's Test Adequacy & 0.814 & & \\
\hline Approx. Chi-Square Value & $528.57^{*}$ & & \\
\hline Variances Explained for Eigen Value $>1$ & 25.33 & 16.21 & 14.41 \\
\hline
\end{tabular}

Source: Extraction Method: Principal Component Analysis, Rotation Method: Varimax with Kaiser Normalization and Rotation converged in 5 iterations. * Significant at 5 Level with degree of freedom 78.

The results of Kaiser-Meyer-Olkin (KMO) and Bartlett's test of Sphericity; variance explain by the three factors and rotated component matrix of the factors analysis for the perceived satisfaction level of selected respondents regarding of factors hold key to job satisfaction of the human resources are shown in Table 2. Bartlett's test of sphericity reveals that the approximate chi-square value is 528.57 with 78 degrees of freedom at 5 percent levels of significance. KMO measures the adequacy of samples estimated by 0.814 revealed the test suitability of factor analysis. It is found that the total variance explain by the three factors is 55.95 percent for the cases where each of the eigenvalues is greater than 1 (one) and 3 (three) factors have been taken out by the principal component analysis. The total variances explained accounted from rotation sums of squared loadings for 55.95 percent consists of 25.33 percent, 16.21 percent and 14.41 percent by the factors F-1 and F-2 and F-3 respectively. Hence, it is conclude that, 13 variables included in the study have been reduced within three factors as Factor-1: Developed monetary based human resources facilities; Factor-2: Technologically advanced facilities based on working conditions; Factor-3: Satisfactory level of practicing autonomy to be the most influential factors which actually reflects key factors of job satisfaction of human resources of TGTDCL in Bangladesh.

The interpretation of the impact of each of job satisfaction related variables on overall mean perceived satisfaction can be explained as the following multiple regression models: 
Table 3. Measures of the outputs of Regression analysis for Job satisfaction of the human resources

\begin{tabular}{lllll}
\hline Variables & $\boldsymbol{\beta}$-coefficient & t-Stat & Sig & VIF \\
\hline Constant & 0.39 & 1.87 & 0.05 & - \\
Job security & 0.14 & 3.60 & 0.00 & 1.51 \\
Salary & 0.11 & 2.19 & 0.03 & 1.40 \\
Promotion & 0.09 & 2.89 & 0.00 & 1.34 \\
Job status & 0.14 & 3.99 & 0.00 & 1.52 \\
Working conditions & 0.09 & 2.31 & 0.02 & 1.42 \\
Supervision & 0.09 & 2.61 & 0.01 & 1.35 \\
Autonomy & 0.09 & 2.89 & 0.00 & 1.61 \\
Participation & 0.16 & 5.35 & 0.00 & \\
R-Square & 0.79 & & & \\
Adjusted R-Square & 0.78 & & & \\
Standard Error of Estimate & 0.30 & & & \\
F- Ratio & $50.10^{*}$ & & & \\
\hline
\end{tabular}

Source: Compiled from primary data by SPSS version: 22, Dependent Variable: overall mean satisfaction Predictors: (Constant), Participation, Supervision, Working conditions, Salary, Job status, Autonomy, Job security, Promotion, * Significant at 5 Level with degree of freedom $(8,106)$

The concerned results for the measurements of the coefficients of the related variables of factors hold key to job satisfaction of the human resources have been depicted in the above mentioned Table 3 where the dependent variable: overall mean satisfaction, predictors: (Constant), participation, supervision, working conditions, salary, job status, autonomy, job security and promotion for the undertaken study. These above mentioned variables were extracted from 13 (thirteen) independent variables as influential contribution to the dependent variables. All the selected independent variables were significant at $(0.00-0.05)$ percent level of significant. In the model, variance inflationary factors (VIF) were found from to be the lower of 1.34 to highest of 1.69 indicates expected acceptable extend of multicollinearity. The coefficient of each of the predictors has positive, unique and significant impact on the dependent variable.

Now with the help of the analysis and interpretations an attempt has been taken to identify the groups of the human resources that divided in their opinions regarding the job satisfaction level to some key variables as discussed in the following table:

Table 4. Measures of the opinion differed among groups for the selected variables related to job satisfaction of the human resources.

\begin{tabular}{|c|c|c|c|c|c|}
\hline Group variable & $\mathbf{N}$ & Mean Rank & Mann-Whitney U & Wilcoxon W & Z-Stat \\
\hline \multicolumn{6}{|c|}{ Measure of continuous variable-Job Security } \\
\hline Family Members $\leq 4$ & 75 & 51.58 & 1018.50 & 3868.50 & $-3.08^{*}$ \\
\hline Family Members $\geq 4$ & 40 & 70.04 & & & \\
\hline \multicolumn{6}{|c|}{ Measure of continuous variable-Working conditions } \\
\hline Family Members $\leq 4$ & 75 & 53.79 & 1184.500 & 4034.500 & $-1.95 *$ \\
\hline Family Members $\geq 4$ & 40 & 65.89 & & & \\
\hline \multicolumn{6}{|c|}{ Measure of continuous variable-Participation } \\
\hline Family Members $\leq 4$ & 75 & 62.41 & 1169 & 1989 & $-2.01 *$ \\
\hline Family Members $\geq 4$ & 40 & 49.73 & & & \\
\hline \multicolumn{6}{|c|}{ Measure of continuous variable-Supervision } \\
\hline Below Bachelor Degree & 26 & 69.58 & 856.00 & 4861.00 & $-2.17 *$ \\
\hline Above Bachelor Degree & 89 & 54.62 & & & \\
\hline \multicolumn{6}{|c|}{ Measures of continuous variable-Communication } \\
\hline Below Bachelor Degree & 26 & 48.54 & 911.00 & 1262.00 & $-1.71 *$ \\
\hline Above Bachelor Degree & 89 & 60.76 & & & \\
\hline \multicolumn{6}{|c|}{ Measures of continuous variable-Participation } \\
\hline Below Bachelor Degree & 26 & 46.00 & 845.00 & 1196.00 & $-2.16^{*}$ \\
\hline Above Bachelor Degree & 89 & 61.51 & & & \\
\hline
\end{tabular}

Source: Compiled from primary data by SPSS version: 22, Mann-Whitney U- Test, * Significant at 5 Level

Mann-Whitney $U$ test techniques has been applied to assess the differences between two independent groups on some continuous measures of the variables like job security, working conditions, participation, supervision and communication. From the analysis of Table 4 it is noted a statistically significant difference among various groups at 5 percent level, has been found for each of the continuous variables including in the above mention interpretation. The higher level of perceived satisfied mean rank score has found in each of the group Family members $\geq 4$ (70.04), Family members $\geq 4$ (65.89), Family members $\leq 4$ (62.41), Below bachelor degree (69.58), Above bachelor degree (60.76) and Above bachelor degree (61.51) respectively for autonomy, job security, working conditions, participation, supervision 
and communication. On the other hand below satisfaction for the same has been found in case of lower mean rank scores.

Table 5. Measures of the opinion differed among groups of salary level for the selected variables related to job satisfaction of the human resources.

\begin{tabular}{|c|c|c|c|c|c|c|c|}
\hline \multirow{2}{*}{ Salary Level (TK.) } & \multirow{2}{*}{$\mathbf{N}$} & \multicolumn{6}{|c|}{ Mean Rank of selected variables related to Job Satisfaction } \\
\hline & & $\mathrm{X} 2$ & X3 & X6 & $\mathrm{X10}$ & $\mathrm{X12}$ & $\mathrm{X13}$ \\
\hline Less than 15000 & 1 & 60.50 & 62.00 & 30.00 & 51.50 & 29.50 & 29.50 \\
\hline $15000-25000$ & 7 & 46.93 & 19.93 & 70.00 & 38.29 & 32.00 & 29.43 \\
\hline $25000-35000$ & 22 & 50.86 & 47.30 & 70.80 & 36.05 & 40.73 & 55.41 \\
\hline $35000-45000$ & 23 & 49.70 & 55.07 & 59.50 & 64.96 & 60.02 & 61.87 \\
\hline $45000-55000$ & 26 & 58.62 & 58.54 & 47.08 & 70.12 & 65.25 & 65.67 \\
\hline More than 55000 & 36 & 69.31 & 73.32 & 55.56 & 62.24 & 67.88 & 57.92 \\
\hline Chi-Square Value & & $10.79 * *$ & $20.35 *$ & $9.19 *$ & $18.39 *$ & $16.43 *$ & $9.59 * *$ \\
\hline
\end{tabular}

Source: Compiled from primary data by SPSS version: 22, Kruskal Wallis Test, Degree of freedom 5; Salary= $(X 2)$, Promotion= $(X 3)$, Supervision= $(X 6)$, Communication $=(X 10)$, Participation $=(X 12)$ Training $=(X 13), N=$ Respondents numbers.

The above Table 5 shows the dissection of the measures of the opinions differed among groups of salary level for the selected continuous variables i.e. salary, promotion, supervision, communication, participation and training related to job satisfaction of the human resources where the variables are statistically significant difference at (0.05-0.10) percent level. The satisfied mean rank scores of the respondents on different categories of salary level for the above mention variables are shown clearly as below:

Table 6. Rank positions of the significant variables.

\begin{tabular}{lllllll}
\hline Variables/ Items & Less than TK.15000 & TK.15000-25000 & TK.25000-35000 & TK.35000-45000 & TK.45000-55000 & More than TK.55000 \\
\hline Salary & 2 & 6 & 4 & 5 & 3 & 1 \\
Promotion & 2 & 6 & 5 & 4 & 3 & 1 \\
Supervision & 6 & 2 & 1 & 3 & 5 & 1 \\
Communication & 4 & 5 & 6 & 2 & 2 & 3 \\
Participation & 6 & 5 & 4 & 3 & 1 \\
Training & 5 & 6 & 4 & 2 & 3 \\
\hline
\end{tabular}

Source: Compiled from Table 5

The above Table 6 reveals the picture focus that the respondents groups of higher salary level (More than TK.55000) and (TK.45000-55000) enjoyed maximum facilities than that of lower group provided by the management of TGTDCL in Bangladesh.

Table 7. Measures of the opinion differed among groups of locations for the selected variables related to Job Satisfaction of the human resources.

\begin{tabular}{|c|c|c|c|c|c|c|c|}
\hline \multirow{2}{*}{ Locations } & \multirow{2}{*}{$\mathbf{N}$} & \multicolumn{6}{|c|}{ Mean Rank of Selected Variables Related to Job Satisfaction } \\
\hline & & $\mathbf{X 1}$ & $\mathbf{X} 2$ & $\mathbf{X 3}$ & X4 & X5 & X6 \\
\hline Head Office & 47 & 55.23 & 55.97 & 60.28 & 62.65 & 55.96 & 50.68 \\
\hline Dhaka & 28 & 68.73 & 67.18 & 70.07 & 67.68 & 61.80 & 65.43 \\
\hline Gazipur & 20 & 39.68 & 43.35 & 40.93 & 37.45 & 40.15 & 53.15 \\
\hline Maymensingh & 10 & 42.75 & 46.25 & 26.80 & 39.80 & 59.20 & 64.45 \\
\hline Narayanganj & 10 & 92.85 & 82.90 & 78.85 & 68.35 & 91.45 & 74.85 \\
\hline Chi-Square Value & & $26.36^{*}$ & $19.03 *$ & $23.15 *$ & $17.11 *$ & $18.08 *$ & $8.17 * *$ \\
\hline Particulars & $\mathbf{N}$ & $\mathbf{X 7}$ & $\mathbf{X 8}$ & $\mathbf{X 1 0}$ & $\mathrm{X} 11$ & $\mathbf{X 1 2}$ & $\mathbf{X 1 3}$ \\
\hline Head Office & 47 & 61.97 & 55.26 & 57.66 & 48.88 & 57.87 & 54.77 \\
\hline Dhaka & 28 & 73.13 & 67.00 & 72.00 & 62.84 & 75.66 & 71.43 \\
\hline Gazipur & 20 & 35.88 & 62.35 & 43.40 & 56.53 & 43.05 & 48.88 \\
\hline Maymensingh & 10 & 33.20 & 37.00 & 28.30 & 86.70 & 30.00 & 44.95 \\
\hline Narayanganj & 10 & 66.05 & 58.00 & 79.30 & 61.55 & 67.05 & 66.90 \\
\hline Chi-Square Value & & $23.14 *$ & $7.87 * *$ & $22.44 *$ & $16.00 *$ & $21.03^{*}$ & $10.88^{*}$ \\
\hline
\end{tabular}

Source: Compiled from primary data by SPSS version: 22, Kruskal Wallis Test, Degree of freedom 4, * significant at 1 percent level, ** significant at 10 percent level. Job Security $=(X 1)$, Salary $=(X 2)$, Promotion $=(X 3)$, Job Status $=(X 4)$, Working Conditions $=(X 5)$, Supervision $=(X 6)$, Award $=(X 7)$, Relation= $(X 8)$, Communication $=(X 10)$, Duration $=(X 11)$, Participation $=(X 12)$ and Training $=(X 13)$

The above Table 7 shows the results of measures of the opinion differed among group of locations for the selected continuous variables job security, salary, promotion, job status, working conditions, award, communication, duration, participation and training related to job satisfaction of the human resources where the variables are statistically significant at 5 percent level except the variable supervision and relation which are at 10 percent level of significant as 
shown by the Chi-Square Value. The satisfaction level of the respondents from different locations for the analyzed variables has been summarized on the basis of mean rank as below:

Table 8. Rank positions of the significant variables based on office location.

\begin{tabular}{|c|c|c|c|c|c|}
\hline Variables/ Items & Head Office & Dhaka & Gazipur & Maymensingh & Narayanganj \\
\hline Job Security & 3 & 2 & 5 & 4 & 1 \\
\hline Salary & 3 & 2 & 5 & 4 & 1 \\
\hline Promotion & 3 & 2 & 4 & 5 & 1 \\
\hline Job Status & 3 & 2 & 5 & 4 & 1 \\
\hline Working Conditions & 4 & 2 & 5 & 3 & 1 \\
\hline Supervision & 5 & 2 & 4 & 3 & 1 \\
\hline Award & 3 & 1 & 4 & 5 & 2 \\
\hline Communication & 3 & 2 & 4 & 5 & 1 \\
\hline Duration & 5 & 2 & 4 & 1 & 3 \\
\hline Participation & 3 & 1 & 4 & 5 & 2 \\
\hline Training & 3 & 1 & 4 & 5 & 2 \\
\hline
\end{tabular}

Source: Compiled from Table 6

From the above picture (Table 8) it is seen that the respondents groups of Narayanganj and Dhaka revel in foremost facilities than that of other located groups provided by the management of TGTDCL in Bangladesh. This discrepancy of non-uniform facilities allocations are the causes of job dissatisfaction of the human resources of the company.

\section{Findings of the Study}

According to the measurements of descriptive statistics of 13 (thirteen) variables included under the study, the results of the satisfaction level of the respondents differ from lower highly dissatisfied to highly satisfied with a valid value of Cronbach's Alpha 0.856 indicating good reliability for analysis. These variables have been reduced to three factors as Factor-1: Developed monetary based human resources facilities; Factor-2: Technologically advanced facilities based on working conditions; Factor-3: Satisfactory level of practicing autonomy to be the most influential that in fact reflect as key factors of job satisfaction of human resources of TGTDCL in Bangladesh. Moreover the regression coefficient of each of the predictors (Constant), participation, supervision, working conditions, salary, job status, autonomy, job security and promotion has positive, unique and significant impact on the dependent variable i.e. overall mean satisfaction. The higher level of perceived satisfied mean rank score was found in each of the group Family members $\geq 4$ (70.04), Family members $\geq 4$ (65.89), Family members $\leq$ 4 (62.41), Below bachelor degree (69.58), Above bachelor degree (60.76) and Above bachelor degree (61.51) respectively for autonomy, job security, working conditions, participation, supervision, communication and participation where the below satisfactions for the same were found to be in case of lower mean rank scores.

The respondents groups of higher salary level (More than TK.55000) and (TK.45000-55000) enjoyed maximum facilities than that of lower groups provided by the management.

The respondents groups of Narayanganj and Dhaka revel in foremost facilities than that of other located groups provided by the management of TGTDCL in Bangladesh. This discrepancy of facilities allocations are the causes of job dissatisfaction of the human resources of the company.

\section{Identified Problems for Dissatisfaction}

On the basis of analysis and interpretations the problems that cases dissatisfactions of the human resources regarding job related facilities of Titas Gas Transmission \& Distribution Company Limited in Bangladesh have been identified as follows:

i) The satisfactions levels regarding management provided facilities of the respondents differ from highly dissatisfy to highly satisfy of employees that impact badly on overall perceived job satisfaction revealed deteriorating profitability and productivity of TGTDCL in Bangladesh.

ii) The employees of the company have been suffering from unhappiness regarding job security, working conditions, participation, supervision and communication among various groups of demographic variables.

iii) The human resources of higher salary groups enjoy maximum additional facilities than that of lower groups provided by the management that effect poorly on job satisfaction of the company.

iv) The discrepancy of facilities allocations among the employees of various locations are the causes of job dissatisfaction of the human resources of the company.

v) The unpleasant feelings regarding autonomy, award, relation, duration and training given by the company are the reasons of job dissatisfaction of the human resources of the company.

\section{Conclusion}

The level of satisfaction of the organizations employees are overall satisfied in the higher positional who are the 
policy maker of the organization but the low level employees who are engaged in the direct operational activities are not satisfied in the various sectors like training, participation, communication, promotion, supervision. As a result the operating profit is not satisfactory at all. Office locations are key factors of the level of employee's satisfaction. Remote areas employees are more dissatisfied than the central area of Dhaka and near Dhaka (Narayanganj). So facilities provided should be adequate and allocated to the employees maintaining equity to ensure legal rights disregarding manipulations of outwards intervention that damages the congenial environment of the organizational environments and lead to dissatisfactions of the human resources.

\section{Suggestions and Recommendations}

The following suggestions are to be recommended to overcome the problems so that the human resources of the company enjoy better job satisfactions that lead higher degree of productivity and profitability:

i) To enhance the pleasure regarding job security of the human resources, the company management should be conformed adequate wages and salary; ensured compensations for retirement or lay-off of the company; make sure to reduce redundancy rates, industry constraints rates, downsizing, and recession; and fitted in to introduce new technology.

ii) To introduce developed monetary based human resources facilities regarding promotion, award, training etc. that will enhance in pay, prestige, position and responsibilities lead to stimulate employees to higher productivity.

iii) To incorporate technologically advanced facilities based working conditions of safe, clean healthy and comfortable physical working environment that will ultimately increase more positive level of job satisfaction.

iv) To ensure satisfactory level of practicing autonomy by providing the employee self-controls, flexibility and free will to do works with trust and communication with the good relationship of the management that will lead to better job satisfaction.

v) To reduce unpleasant feelings regarding autonomy, award, relation, duration and training, the authority should take proper policy to raise better job satisfaction level of the human resources of the company.

\section{References}

[1] Abuhashesh, M., Rand Al-Dmour and Ra'ed Masa'deh (2019). Factors that affect Employees Job Satisfaction and Performance to Increase Customers' Satisfactions. Journal of Human Resources Management Research. Vol. 2019 (2019).123 Article ID 354277. DOI: 10.5171/2019.354277, Retrieved from

https://ibimapublishing.com/articles/JHRMR/2019/354277/35 4277.pdf.

[2] Aswathappa A. (2009). Human Resource Management: Text and Cases (Fifth edition). Tata McGraw-Hill Publishing Company Limited, New Delhi 110 008, India.

[3] Burchell B. (2014) Job Security. In: Michalos A. C. (eds) Encyclopedia of Quality of Life and Well-Being Research. Springer, Dordrecht. https://doi.org/10.1007/978-94-0070753-5 1569, Retrieved from https://ink.springer.com/referenceworkentry/10.1007\%2F97894-007-0753-5_1569.

[4] Feldman, M. S., Skoldberg, K., Brown, R. N. \& Horner, D. (1983). Making Sense of Stories: A Rhetorical Approach to Narrative Analysis. Journal of Public Administration Research and Theory, 14 (2), 147-170, DOI: 10.1093/jopart/muh010.

[5] Hee, O. C., Yan, L. H., Rizal, A. M., Kowang, T. O., \& Fei, G. C. (2018). Factors Influencing Employee Job Satisfaction: A Conceptual Analysis. International Journal of Academic Research in Business and Social Sciences, 8 (6), 331-340.

[6] Jevinani, S. M. S. \& Amoozegar, A. (2020). Job satisfaction among Malaysian Employees: A Review Study, Sapiens Journal of Modern Education, 2 (2), 5-11 Retrieved from https://www.academia.edu/44079467/Job_Satisfaction_among _Malaysian_Employees_A_Review_Study.

[7] Mahapatra, B. B. (2010). Human Resource Management. New Age International (P) Ltd., Publishers, New Delhi, India.

[8] Malhotra, N. K., \& Dash, S. (2010). Marketing Research An Applied Orientation. Delhi: Pearson Prentice Hall.

[9] Mishra, P. K. (2013). Job Satisfaction. IOSR Journal of Humanities and Social Science (IOSR-JHSS). 14 (5), 45-54. www.iosrjournals.org.

[10] Robbins, S. P. (2001). Organizational behavior ( $9^{\text {th }}$ editions). Prentice Hall International, Inc., Uper Saddler River, New Jersey, 0745.

[11] Roy, B. N., Hossain, M. A. \& Shammi, E. G. (2017). Job Satisfaction of the Bank Employees in Bangladesh: A Study in Bogra City. American Scientific Research Journal For Engineering, Technology, and Sciences (ASRJETS). 37 (1), 34-43, http://asrjetsjournal.org.

[12] Shaju. M and Subhashini. D (2017). A study on the impact of Job Satisfaction on Job Performance of Employees working in Automobile Industry, Punjab, India. Journal of Management Research, 9 (1), 117-130, Retrieved from https://www.researchgate.net/publication/313334566_A_study_ on_the_impact_of_Job_Satisfaction_on_Job_Performance_of_Employees_working_in_Automobile_Industry_Punjab_India.

[13] https://www.titasgas.org.bd//temp/source/AR20192020.pdf.

[14] www.managementstudyguide.com/herzbergs-theorymotivation.htm.

[15] http://www.petrobangla.org.bd/sites/default/files/files/petroba ngla.portal.gov.bd/annual_reports/f734b418_c1fc_4913_8197 $35 \mathrm{f} 2 \mathrm{db} 29 \mathrm{cff} 1 / 2021-01-10-14-49$ fd5f00a3flbabfa8f051d2d335c045b7.pdf.

[16] https://mof.portal.gov.bd/sites/default/files/files/mof.portal.go v.bd/page/ebb460ed_b1f5_4fa1_bd1b_e08f87400002/Public\% 20Bodies.pdf. 